\title{
9. Will ASEAN mutual recognition arrangements induce skilled workers to move? A case study of the engineering labor market in Thailand
}

\section{Sasiwimon Warunsiri Paweenawat and Jessica Vechbanyongratana}

\section{INTRODUCTION}

One of the main features of the ASEAN Economic Community (AEC) is the free movement of skilled workers in eight employment categories under the mutual recognition arrangement (MRA). The agreement should lower migration costs, leading to increased movement of skilled workers across ASEAN countries. In particular, the agreement removes some entry barriers through common licensing and easier access to work visas. Since 2015, registered ASEAN professionals have migrated to work in other ASEAN countries. But it remains to be seen whether the agreement significantly affects job decisions of skilled labor. This chapter examines Thailand's market for engineers - one of the MRA professional classesand discusses the potential movement of Thai engineers based on the costs and benefits. It also looks at the potential attractiveness of the Thai market for engineers from other ASEAN countries.

The ASEAN MRA on engineering services was the first MRA signed and has been in force since 2005. However, only in 2013 did all ASEAN members fully join. The ASEAN Chartered Professional Engineer Coordinating Committee (ACPECC) is the central professional organization that recognizes engineering qualifications in the region. It allows registered engineers to work in other ASEAN countries immediately after registering as a Registered Foreign Professional Engineer (RFPE) in the host country. However, the number of registered engineers remains very low. 
Table 9.1 Current registered engineers on the ACPE database

\begin{tabular}{lc}
\hline Country & Number of Registered Engineers \\
\hline Brunei Darussalam & 8 \\
Cambodia & 30 \\
Indonesia & 847 \\
Lao People's Democratic Republic & 12 \\
Malaysia & 284 \\
Myanmar & 239 \\
Philippines & 205 \\
Singapore & 252 \\
Thailand & 158 \\
Viet Nam & 196 \\
Total Engineers & 2,231 \\
\hline
\end{tabular}

Note: $\quad$ ACPE $=$ ASEAN Chartered Professional Engineer.

Source: ASEAN Chartered Professional Engineer Coordinating Committee (ACPECC) (as of December 2016).

As of December 2016, only 2,231 engineers had registered as an ASEAN Chartered Professional Engineer (ACPE), with just 158 from Thailand (Table 9.1). One study found that Thai engineers compared well against those from other ASEAN countries (University of the Thai Chamber of Commerce 2012). So why have so few Thai engineers registered as ASEAN engineers if they are leaders in the region?

From the demand side, Thailand is often assumed to have a shortage of workers in science, technology, engineering, and mathematics - the "STEM" fields. However, a recent paper by Paweenawat and Vechbanyongratana (2015) on the returns to STEM education and employment in Thailand finds there is no shortage of STEM degree holders. Rather, only $29 \%$ of STEM graduates have STEM-related jobs. They receive higher returns in non-STEM occupations.

From the supply side, the market for engineers and possible impact of the ASEAN MRA come into play. Paweenawat and Vechbanyongratana indicate there is a large mismatch in this portion of the labor market. Engineering graduates largely do not work as engineers due to factors such as the lack of appropriate jobs and low returns on education compared with non-engineering fields like finance, for example. These need to be better understood.

This chapter thus asks whether Thai engineers would take advantage of opening regional skilled labor markets given current labor market conditions for engineers in Thailand. It addresses the supply side of the 
market by investigating the number of Thai postsecondary engineering graduates currently in or expected to join the labor market. It then assesses how close engineering graduates match jobs commensurate with their qualifications in Thailand - and the relative wage returns they can expect for both engineering degrees and engineering occupations in Thailand. The chapter briefly discusses Thailand's current demand for engineering graduates. Finally, it discusses the potential impact of regional integration on the engineering labor market.

The study first utilizes a probit regression to assess the probability that workers trained as engineers find formal employment in a largely informal labor market. An augmented Mincer wage regression is then used to analyze wage returns to engineering degrees and occupations. The analysis finds a 5\% higher probability of engineering graduates finding formal employment compared with business and social science graduates assumed to have similar analytical skills. Furthermore, the rate of return to engineering degrees/jobs is high compared with other degree/job fields. Given the empirical results and good labor market conditions for engineers in Thailand, one would expect limited movement of Thai engineers into other ASEAN countries. Yet Thailand may be attractive for engineers from other ASEAN countries. Thus, we suggest the Thai government should better prepare its engineers and create incentives for them to work overseas.

The chapter is organized as follows. Section 2 reviews studies relating to the decision to migrate for employment and the wage returns to higher education. Section 3 introduces the methodology and data used to estimate the probabilities of Thai engineers engaging in formal employment and relative wage returns to engineering education and occupations. Sections 4 and 5 present the results and conclusions, respectively.

\section{LITERATURE REVIEW}

\subsection{The Decision to Migrate for Employment}

Economists generally analyze the decision to migrate based on a costbenefit framework. Sjaastad (1962) stated that a person will compare the current value of the expected return and the cost of migration. Bauer et al. (2005) clearly outline the potential costs and benefits of migrating abroad for employment, summarized as follows:

- Benefits

o Monetary

o Increased labor earnings in new job 
- Non-monetary

o Attractive climate

o Good work environment

- Costs

o Monetary

- Travel expenses

- Employment search costs

o Non-monetary

- Forgone earnings at home

- Psychological costs arising from the loss of a familiar environment and confrontation with another culture.

According to Bodker et al. (2013, p.5), more successful workers in the labor market generally have higher direct and indirect costs. This means that the benefits need to be relatively high for skilled workers to overcome the inherent costs of migration. In fact, Borjas (1987) suggests that highskilled workers tend to migrate to countries where skill prices are relatively high.

The European Union (EU) - the classic model of regional economic and monetary integration - holds several lessons, as free labor mobility within the EU is one of its main pillars. Bonin et al. (2008) found from their survey that the movement of workers within the EU15, EU12, and EU27 has been driven by two main factors - jobs and family. Manpower (2008) particularly focused on the movement of high-skilled workers within the EU, finding that higher compensation is the most significant factor leading to movement within this group.

Kahanec (2012) found that even though the EU worked toward establishing MRAs for professional qualifications - to ease high-skilled labor migration within the EU-the mobility rate remained relatively low compared with other single currency areas such as Australia, Canada, the Russian Federation, and the United States. Interestingly, he found that MRAs facilitated recognition of professional credentials, but their implementation was difficult. Barriers to EU labor mobility included taxation, social security and health insurance problems, as well as difficulties in the work itself. Furthermore, Eurofound (2014) said that language was also a major impediment for intra-EU mobility. Based on the 2010 Eurobarometer survey on geographical and labor market mobility by the European Commission (2010), more than half of the respondents mentioned that language differences were considered a barrier to intraEU migration. Together these barriers could explain the low rates of EU skilled worker mobility compared with other regions.

A study by Sugiyarto and Agunias (2014, p.4) asserts that the "AEC 
does not guarantee or seek full labor mobility even among the highly skilled, it only facilitates this movement"-weaker than labor agreements in the EU and the Caribbean Community (CARICOM). The EU allows free labor movement at all skill levels, while CARICOM provides high-skilled workers with free entry visas within the region. As a result, ASEAN's intention of free movement is "less ambitious" by comparison (Sugiyarto and Agunias 2014, p.4).

United Nations (2013) says that $70 \%$ of total ASEAN migrants come from other ASEAN countries. The vast majority of intra-ASEAN migrants (87\%) are low-skilled workers (Orbeta 2013) -leaving the migration flow between high- and low-skilled workers extremely unbalanced. There are only eight MRAs - covering accounting, engineering, nursing, architecture, medicine, dentistry, tourism, and surveying - or about 1.5\% of the ASEAN workforce (Johnson 2015). As MRAs are highly selective by design - and 97\% migrate between just three countries (Thailand, Malaysia, and Singapore) (Migration Policy Institute 2013) - it is not surprising that Sugiyarto and Agunias (2014, p.8) conclude that "[t]he progress on realizing ASEAN's vision has in general been very slow and uneven, despite the stated deadline of 2015." Furthermore, they determine that, based on the results of studies in other regions in the world, most successful MRAs are just part of broader mobility and economic cooperation strategies.

\subsection{Wage Returns to Higher Education}

As this chapter focuses on skilled workers' decision to migrate, the returns to higher education - especially for particular degrees - is important. Berger (1988) was the first to investigate the relationship between predicted future earnings and a student's choice of major. Several studies since have estimated the returns to university degrees with various results. For example, even though some show that STEM graduates on average earn more than non-STEM graduates (O'Leary and Sloane 2005; Webber 2014b), others find there is no wage premium for science graduates (Walker and Zhu 2010). Despite the mixed results, a recent study by Webber (2014a) concludes that, in general, returns to education for highly educated workers differ by type of university degree.

Aside from the degree earned, the occupation chosen after graduation is a key factor in determining earnings. Chevalier (2012) finds that STEM occupations - not degrees - determine wage returns in the United Kingdom. Other studies explored how matching degrees with occupation can determine earnings. For example, Borghans and De Grip (2000) find a positive wage return for those working in occupations that match their 
degrees, while Hoekstra (2009) indicates there is a wage penalty for those who do not match. In addition, Kinsler and Pavan (2015) show that STEM graduates earn a $30 \%$ wage premium if they work in an occupation that matches their major.

Labor market returns for those with engineering degrees have been studied. Fan and Zhang (2015) found the rate of return in engineering is highest or relatively high compared with other degrees. This is consistent with other studies (Thomas 2000) that found workers who graduated with engineering majors received the highest initial salaries compared with those majoring in other fields. Based on the American Community Survey (2009-2010) data, Arcidiacono et al. (2014, p. 1) also found that engineering graduates receive higher earnings than humanities graduates. Similarly, Black et al. (2003) note that, while workers with economics degrees have higher earnings relative to other majors, their earnings remain below those of engineering graduates.

Most studies investigate returns to engineering education and occupations in advanced economies. In one of the few studies that consider labor market returns to engineering degrees in emerging economies, Bourne and Dass (2003) found that the rate of return to engineering degrees was highest among all degrees in Caribbean countries. The most closely related study on Thailand is by Paweenawat and Vechbanyongratana (2015), which estimates private returns to STEM education. The results show that occupational choice largely determines wages, not the degree earned. By analyzing returns to engineering education and occupations in Thailand, this chapter provides the relevant context in which to discuss the potential impact of ASEAN MRAs.

\section{DATA AND METHODOLOGY}

Descriptive and econometric approaches are used to create a holistic picture of Thailand's current market for engineers. Existing market surveys and studies help assess the current supply and demand for engineers in Thailand. Then a supply-side analysis is conducted using data from the 2007-2009 Thai Labor Force Surveys (LFS) — compiled by the National Statistical Office of Thailand, Statistical Forecasting Bureau. Each quarterly LFS represents data compiled from interviews with the household head or other member. Each survey covers 70,000-200,000 people or $0.1-0.5 \%$ of the population. The estimation uses the 3rd quarter survey because the sample size is relatively larger and complete compared with surveys from other quarters - due to the effect of seasonal agricultural migrants. LFS surveys are used to estimate the number of postsecondary 
engineering degree holders in Thailand and the number of people engaged in engineering professions. The data are also used to determine how closely engineering degree holders match with their employment, the probability of engaging in formal employment, and the wage returns to engineers relative to non-engineers.

The sample includes full-time workers (more than 30 hours a week) between 16 and 59 years old at the time of the survey with a four-year university degree or higher. The full sample contains 49,021 observations, of which 35,072 were wage earners.

Work status falls under seven main categories - (i) employers, (ii) selfemployed without employees, (iii) unpaid family workers, (iv) government employees, (v) government enterprise employees, (vi) private employees, and (vii) members of cooperatives. Although the relationship between degree type and formal employment is important, there is no LFS variable directly indicating formal employment. As a proxy, a dummy variable for formal employment is used that includes employers and government, government enterprise, and private firm employees. The other categories are considered informally employed.

The LFS classifies occupations according to the International Standard Classification of Occupations 1988 (ISCO-88) codes. A worker is classified as working in engineering as defined by the Occupational Information Network's (O*NET) STEM classification system. ${ }^{1}$ O*NET uses the Standard Occupational Classification (SOC), thus the SOC codes were converted using the United States Bureau of Labor Statistics' crosswalk with ISCO-08 (2008 update to ISCO-88), then converted again using the ISCO-08/ISCO-88 crosswalk. Most occupations classified as engineering jobs are obvious. A worker is also classified as having an engineering degree if their degree field is code 52 according to the International Standard Classification of Education (ISCED) (Table 9.2).

The summary statistics are also stratified by degree type. Employees with engineering degrees differ from the rest of the sample in several important ways. For example, employees with engineering degrees earn on average THB3,438 more per month than employees without engineering credentials. Also, fewer engineers pursue graduate-level education, possibly because the return on undergraduate degrees is relatively high in Thailand. Women comprise only $7 \%$ of engineering graduates, whereas they represent $62 \%$ of employees with bachelor degrees. Finally, workers with engineering credentials are more likely to be in Bangkok and central Thailand, where most engineering work is located.

Paweenawat and Vechbanyongratana (2015) showed that career matching for engineering graduates is much higher than for other science and 
Table 9.2 Summary statistics

\begin{tabular}{|c|c|c|c|c|}
\hline Variable & Total & $\begin{array}{l}\text { Non- } \\
\text { Engineering } \\
\text { Degree }\end{array}$ & $\begin{array}{l}\text { Engineering } \\
\text { Degree }\end{array}$ & $\begin{array}{l}\text { t-statistic/ } \\
\text { z-statistic }\end{array}$ \\
\hline $\begin{array}{l}\text { Formal Employment } \\
\text { Indicator }\end{array}$ & $\begin{array}{c}0.762 \\
(0.426)\end{array}$ & $\begin{array}{c}0.761 \\
(0.426)\end{array}$ & $\begin{array}{c}0.765 \\
(0.424)\end{array}$ & $\begin{array}{r}-0.42 \\
\ldots\end{array}$ \\
\hline $\begin{array}{l}\text { Real monthly income } \\
\text { (USD1 = THB35.23 as } \\
\text { of } 10 \text { May 2016) }\end{array}$ & $\begin{array}{c}17,850.25 \\
(14,447.82)\end{array}$ & $\begin{array}{c}17,712.29 \\
(14,327.05)\end{array}$ & $\begin{array}{c}21,150.62 \\
(16,754.83)\end{array}$ & $\begin{array}{c}-8.76^{* * * *} \\
\ldots\end{array}$ \\
\hline MA/PhD Degree Indicator & $\begin{array}{c}0.104 \\
(0.305)\end{array}$ & $\begin{array}{c}0.105 \\
(0.306)\end{array}$ & $\begin{array}{c}0.086 \\
(0.281)\end{array}$ & $2.72 * * *$ \\
\hline Engineering Degree & $\begin{array}{c}0.043 \\
(0.203)\end{array}$ & $\begin{array}{l}\ldots \\
\ldots\end{array}$ & $\begin{array}{l}\ldots \\
\ldots\end{array}$ & $\begin{array}{l}\cdots \\
\ldots\end{array}$ \\
\hline Engineering Occupation & $\begin{array}{c}0.046 \\
(0.210)\end{array}$ & $\begin{array}{c}0.034 \\
(0.180)\end{array}$ & $\begin{array}{c}0.330 \\
(0.470)\end{array}$ & $-63.38 * * *$ \\
\hline Female Indicator & $\begin{array}{c}0.596 \\
(0.491)\end{array}$ & $\begin{array}{c}0.620 \\
(0.485)\end{array}$ & $\begin{array}{c}0.069 \\
(0.254)\end{array}$ & $17.19 * * *$ \\
\hline Age & $\begin{array}{l}38.304 \\
(9.959)\end{array}$ & $\begin{array}{l}38.467 \\
(9.986)\end{array}$ & $\begin{array}{l}34.669 \\
(8.582)\end{array}$ & $50.45^{* * *}$ \\
\hline Married Indicator & $\begin{array}{c}0.602 \\
(0.489)\end{array}$ & $\begin{array}{l}0.603 \\
(0.489)\end{array}$ & $\begin{array}{l}0.571 \\
(0.495)\end{array}$ & $3.02 * * *$ \\
\hline Urban Indicator & $\begin{array}{c}0.544 \\
(0.498)\end{array}$ & $\begin{array}{c}0.544 \\
(0.498)\end{array}$ & $\begin{array}{c}0.541 \\
(0.498)\end{array}$ & 0.28 \\
\hline Public Employee Indicator & $\begin{array}{c}0.484 \\
(0.500)\end{array}$ & $\begin{array}{c}0.494 \\
(0.500)\end{array}$ & $\begin{array}{l}0.268 \\
(0.443)\end{array}$ & $20.35 * * *$ \\
\hline Bangkok Metropolitan Area & $\begin{array}{c}0.120 \\
(0.325)\end{array}$ & $\begin{array}{c}0.116 \\
(0.320)\end{array}$ & $\begin{array}{c}0.206 \\
(0.404)\end{array}$ & $-12.38 * * *$ \\
\hline Central Region & $\begin{array}{c}0.307 \\
(0.461)\end{array}$ & $\begin{array}{c}0.302 \\
(0.459)\end{array}$ & $\begin{array}{c}0.409 \\
(0.492)\end{array}$ & $-10.39 * * *$ \\
\hline Northern Region & $\begin{array}{c}0.194 \\
(0.395)\end{array}$ & $\begin{array}{c}0.197 \\
(0.398)\end{array}$ & $\begin{array}{c}0.124 \\
(0.329)\end{array}$ & $8.33 * * *$ \\
\hline Northeastern Region & $\begin{array}{c}0.223 \\
(0.416)\end{array}$ & $\begin{array}{c}0.226 \\
(0.418)\end{array}$ & $\begin{array}{c}0.153 \\
(0.360)\end{array}$ & $7.88 * * *$ \\
\hline Southern Region & $\begin{array}{l}0.156 \\
(0.363)\end{array}$ & $\begin{array}{c}0.158 \\
(0.365)\end{array}$ & $\begin{array}{l}0.109 \\
(0.311)\end{array}$ & $6.18 * * *$ \\
\hline Observations & 49,021 & 46,911 & 2,110 & \\
\hline
\end{tabular}

Note: $\quad$ USD $=$ United States dollar, THB $=$ Thai baht.

Source: Authors' calculations. 
Table 9.3 Cross-tabulations of engineering degree, engineering job, and formal sector employment matching for postsecondary degree holders

Panel A

\begin{tabular}{lccr}
\hline & $\begin{array}{c}\text { Non-Engineering } \\
\text { Degree }\end{array}$ & $\begin{array}{c}\text { Engineering } \\
\text { Degree }\end{array}$ & Total \\
\hline Non-Engineering Job & 45,338 & 1,414 & 46,752 \\
Engineering Job & 1,573 & 696 & 2,269 \\
Total & 46,911 & 2,110 & 49,021 \\
\hline Panel B & \multicolumn{3}{c}{} \\
\hline & Informal & Formal & Total \\
& Employment & Employment & \\
\hline Non-Engineering Degree & 11,190 & 35,721 & 46,911 \\
Engineering Degree & 495 & 1,615 & 2,110 \\
Total & 11,685 & 37,336 & 49,021 \\
\hline Panel C & \multicolumn{3}{c}{} \\
\hline \multicolumn{3}{c}{ Formal } & Total \\
& Informal & Employment & \\
\hline Non-Engineering Occupation & 11,649 & 35,103 & 46,752 \\
Engineering Occupation & 36 & 2,233 & 2,269 \\
Total & 11,685 & 37,336 & 49,021 \\
\hline
\end{tabular}

Source: Paweenawat and Vechbanyongratana (2015) and authors' calculations.

technology fields. A cross tabulation can be done matching engineering degrees, engineering jobs, and formality (Table 9.3).

Panel A indicates that about $31 \%$ of postsecondary engineering graduates match with engineering jobs, well above the $17 \%$ match rate for those with degrees in other STEM fields (Paweenawat and Vechbanyongratana 2015). Although about two-thirds of the workforce is informal, less than a quarter of postsecondary engineering graduates and $2 \%$ of postsecondary degree holders in engineering occupations are informally employed (see Table 9.3, panels B and C). Overall, it appears that the formal Thai economy can absorb trained engineers in the formal market relatively easily — with labor protection and benefits.

The econometric study analyzes two aspects of Thailand's labor market for engineers. The first is the probability that an engineer or engineering graduate will work in the formal economy. The second looks at wage returns to engineering occupations and degrees relative to non-engineering 
occupations and degrees. The analysis also considers whether female engineers experience different rates of formality and wage levels than male engineers. This helps shed light on whether an engineer has an advantage or disadvantage compared with other occupations and degrees in finding formal employment with protection and benefits. Furthermore, the empirical analysis determines an engineer's relative earning power vis-à-vis non-engineers.

\subsection{Probit Regressions}

The first analysis uses a probit regression to model the sorting of engineering graduates relative to non-engineering graduates into Thailand's formal and informal economies. Approximately one-third of the labor force is formally employed - formality is generally defined as being covered by one of the government social security systems (Schmitt et al. 2013). Formality affords the worker a set of employment protections, including worker compensation, unemployment insurance, pension, and maternity benefits, among others. As mentioned, the LFS does not directly classify workers as formal or informal. Rather, workers are classified as employers, employees, or non-employees. ${ }^{2}$ Here "employees" and "employers" are considered working in the formal sector and "non-employees" as informal workers. While this classification can be problematic - as some private firms practice social evasion - private firms are for the most part in compliance with social security laws. Thus most private firm workers with postsecondary credentials are formal sector workers. Employers are also included in the formal economy as it is assumed those in a position to hire others can also afford public or private insurance protection. Of the 49,021 observations on postsecondary graduates, $76 \%$ are classified employees or employers, and thus assumed to work in the formal sector. The variable "formal employment" is a binary outcome variable, where it takes on the value of " 1 " if the graduate works as an employee or employer and " 0 " otherwise.

The probit model is

$$
\operatorname{Pr}(Y=1 \mid X)=f\left(\begin{array}{l}
\text { engineering degree, female, female* engineering degree, } \\
M A / P H D, \text { age }, \text { urban, } \text { married, region }
\end{array}\right)
$$

Controls exist for engineering degree, gender (female), an interaction between female worker and engineering degree, master's or doctorate (MA/PHD) degree completed, age, urban, married, and region. The probability of engineering graduates sorting into the formal sector 
relative to non-engineering graduates is then estimated. The first probit estimation compares the probability of engineering graduates entering the formal sector compared with other degree holders. The sample is then split into two groups: engineering graduates (ISCED 52) and social science and business graduates (ISCED 31 social sciences and 34 business). The results of the second probit estimation compares the probability of being formally employed between engineering graduates and social science and business graduates-assumed to have similar analytical skills/ability as engineering graduates based on Blundell et al. (2000). Finally, only engineering graduates are examined (probit 3) to determine the factors that lead some engineers to find employment in the informal sector.

\subsection{Augmented Mincerian Regressions}

The second part of the analysis utilizes an augmented Mincer wage regression to explore the returns to engineering education and engineering employment in the formal labor market relative to non-engineering degrees and occupations in Thailand. Postsecondary degrees in the formal labor market (35,072 observations report wages and are classified as employees) are estimated using the following augmented Mincerian equation:

$$
\ln w_{i}=\beta_{0}+\beta_{1} M A / P H D_{i}+\operatorname{Deg}_{i} \phi+X_{i} \gamma+\varepsilon_{i}
$$

where $\ln w_{i}$ is natural logarithm of real monthly wages, $M A / P H D$ equals 1 if the respondent holds an MA or $\mathrm{PhD}$ degree, $D e g_{i}$ is a vector of dummy variables indicating the postsecondary degree earned (engineering is the base category), and $\varepsilon_{i}$ is an error term. Vector $X_{i}$ controls for the other factors that can influence wages - including age, age squared, gender, residence (urban/rural), marital status (married/non-married), region (Bangkok, Central, North, Northeast, South), public sector employment, and survey year (2007-2009). A second specification concentrates on the returns to engineering degrees and engineering jobs by adding the dummy variable, $E D_{i}$, which equals 1 if the individual has an engineering degree, and $E J_{i}$, which equals 1 if the individual has an engineering job. Thus, $\beta_{1}$ and $\beta_{2}$ are the returns to a postsecondary engineering degree and to an engineering job, respectively. To test for the additional returns to matching in the labor market (an engineering degree holder is engaged in an engineering job), the interaction term $\left(E D_{i}{ }^{*} E J_{i}\right)$ is added in the regression equation. Thus, $\beta_{3}$ captures the additional wage return to engineers who match the labor market. $E D_{i}$ and $E J_{i}$ also interact with female $e_{i}$ to determine if female engineers have different labor market returns than male engineers. 


$$
\begin{aligned}
& \ln w_{i}=\beta_{0}+\beta_{1} E D_{i}+\beta_{2} E J_{i}+\beta_{3}\left(E D_{i} * E J_{i}\right)+\beta_{4} \text { female }_{i}+ \\
& \beta_{5}\left(\text { female }_{i} * E D_{i}\right)+\beta_{6}\left(\text { female }_{i} * E J_{i}\right)+\beta_{7}\left(\text { female }_{i} * E D_{i} * E J_{i}\right)+ \\
& \beta_{8} M A / P H D+X_{i} \gamma+\varepsilon i
\end{aligned}
$$

For this specification, the returns are first compared with engineering degrees and engineering jobs with non-engineering graduates (entire sample). Then, the returns to business/social science graduates are compared with engineering graduates. Finally, only engineering graduates are analyzed to determine the role matching plays on wages.

It is well recognized that the coefficient on schooling variables in Mincerean regressions suffers from systematic bias due to unobserved ability (Card 1999). This problem is compounded as it is likely that individuals self-select into engineering degrees and occupations because they are high-ability individuals who can cope with course materials. For example, Leslie (2003) finds that high-ability students systematically select science and technology degrees. Although there are no current studies on the correlation between student ability and acceptance into engineering degree programs, it is widely believed engineering programs are some of the most competitive programs for admission in Thailand. Initially, this apparent bias might seem problematic. However, accurately estimating the relative returns to engineering degrees is less interesting than the overall position engineering graduates hold in wage distribution. If their position based on level of education, degree pursued, and unobserved ability is favorable compared with non-engineers, this can influence a decision to migrate (or not) for employment.

\section{RESULTS AND DISCUSSION}

\subsection{Relative Probability of Engineering Graduates Being Formally Employed}

The probit regressions provide details on the relative probability engineering graduates are formally employed compared with workers with other postsecondary qualifications. The probit uses three different stratifications (Table 9.4). The first compares the relative probability of engineering graduates to non-engineering graduates being employed in the formal sector. The second limits the analysis to engineering degree holders and business/ social science degree holders. The idea here is to look at the labor market outcomes of engineering graduates compared with a group of graduates with similar academic strengths (analytical skills) to see if one group has a 
Table 9.4 Probability of engaging in formal employment (probit regressions)

\begin{tabular}{|c|c|c|c|}
\hline \multirow[t]{3}{*}{ Variables } & (1) & (2) & (3) \\
\hline & Entire Sample & $\begin{array}{c}\text { Selected } \\
\text { Postsecondary } \\
\text { Degrees }\end{array}$ & $\begin{array}{l}\text { Engineering } \\
\text { Degrees Only }\end{array}$ \\
\hline & \multicolumn{3}{|c|}{ Dependent Variable: Employee } \\
\hline Engineering Degree & $\begin{array}{l}0.018^{*} \\
(0.010)\end{array}$ & $\begin{array}{l}0.051^{* * * *} \\
(0.011)\end{array}$ & \\
\hline Female Indicator & $\begin{array}{c}-0.005 \\
(0.004)\end{array}$ & $\begin{array}{c}-0.031 * * * \\
(0.007)\end{array}$ & $\begin{array}{c}-0.037 \\
(0.039)\end{array}$ \\
\hline $\begin{array}{l}\text { Female X Engineering } \\
\text { Degree }\end{array}$ & -0.030 & $\begin{array}{r}-0.028 \\
(0.043)\end{array}$ & \\
\hline MA/PhD Degree Indicator & $\begin{array}{l}0.134 * * * \\
(0.005)\end{array}$ & $\begin{array}{l}0.132 * * * \\
(0.009)\end{array}$ & $\begin{array}{l}0.118^{* * * *} \\
(0.028)\end{array}$ \\
\hline Age & $\begin{array}{l}0.003^{* * *} \\
(0.000)\end{array}$ & $\begin{array}{l}0.001 * * * \\
(0.000)\end{array}$ & $\begin{array}{l}0.003^{* *} \\
(0.001)\end{array}$ \\
\hline Urban Indicator & $\begin{array}{l}-0.021 * * * \\
(0.004)\end{array}$ & $\begin{array}{c}-0.026^{* * *} \\
(0.006)\end{array}$ & $\begin{array}{c}-0.014 \\
(0.018)\end{array}$ \\
\hline Married Indicator & $\begin{array}{c}0.006 \\
(0.004)\end{array}$ & $\begin{array}{c}-0.014 * * \\
(0.007)\end{array}$ & $\begin{array}{l}0.054^{* *} \\
(0.022)\end{array}$ \\
\hline Central Region & $\begin{array}{l}-0.029 * * * \\
(0.007)\end{array}$ & $\begin{array}{l}-0.092 * * * \\
(0.011)\end{array}$ & $\begin{array}{l}-0.086 * * * \\
(0.028)\end{array}$ \\
\hline Northern Region & $\begin{array}{l}-0.032 * * * \\
(0.007)\end{array}$ & $\begin{array}{l}-0.125^{* * *} \\
(0.012)\end{array}$ & $\begin{array}{c}-0.202 * * * \\
(0.042)\end{array}$ \\
\hline Northeastern Region & $\begin{array}{c}0.012^{*} \\
(0.007)\end{array}$ & $\begin{array}{c}-0.092 * * * \\
(0.012)\end{array}$ & $\begin{array}{c}-0.205^{* * *} \\
(0.039)\end{array}$ \\
\hline Southern Region & $\begin{array}{c}-0.026^{* * *} \\
(0.008)\end{array}$ & $\begin{array}{c}-0.130^{* * *} \\
(0.013)\end{array}$ & $\begin{array}{c}-0.207 * * * \\
(0.044)\end{array}$ \\
\hline Observations & 49,021 & 21,241 & 2,110 \\
\hline
\end{tabular}

Note: $\mathrm{MA}=$ master's degree, $\mathrm{PHD}=$ doctorate.

Source: Authors' calculations.

relative advantage of finding formal employment. The final specification limits the analysis to engineering graduates. The results here will point to individual characteristics correlated with securing formal employment.

Overall, only $24 \%$ of postsecondary degree holders are informally employed, compared with two-thirds of the overall labor force. The regression results indicate that engineering graduates have a modest $2 \%$ 
advantage over others with postsecondary degrees of being formally employed after controlling for education level, region of residence, and personal characteristics for the entire sample. However, in the second specification, engineering graduates have a $5 \%$ higher probability of finding formal employment. In general, women have about the same or slightly lower probability of being employed in the formal sector as men. The interaction term between female and engineering degree, however, indicates that female engineering graduates do not have any additional disadvantage or advantage compared with male engineering graduates. Thus, it appears that both male and female engineering graduates have approximately the same or higher probability of working in the formal sector as other skilled workers. Although the proportion of skilled workers who work informally is relatively small compared with the overall labor market, the fact remains that nearly a quarter of engineering graduates are informally employed. It is difficult to ascertain whether this is by choice or due to lack of opportunity.

The third specification results suggest that education level and region of residence matter to engineers. In particular, $\mathrm{MA}$ and $\mathrm{PhD}$ holders are $12 \%$ more likely to be formally employed than bachelor degree holders. Also, those who live in the Bangkok metropolitan area-where the majority of skilled jobs are located - are more likely to be formally employed.

Although Thailand's labor market is largely informal, $23 \%$ of engineering degree holders and only around $2 \%$ of those who hold engineering occupations are informally employed. Relative to other skilled workers with university credentials, engineers have approximately the same or slightly better probability of being formally employed. Within engineers, those with high educational attainment (MA or $\mathrm{PhD}$ ) and those who live in Bangkok have higher probabilities of formal employment. With engineers largely enjoying formal employment opportunities in Thailand, it is unlikely that Thai engineers would seek employment abroad for formal employment or to gain employment protections.

\subsection{Relative Wage Returns to Engineering Degrees and Occupations}

The next part of the analysis looks at the relative wage returns of engineering graduates and practitioners and their position in Thailand's wage distribution for skilled workers (Table 9.5). The first specification looks at the relative returns of engineering graduates to graduates in other fields. The second also looks at returns to engineering employment and matching. The third limits the sample to compare relative returns of engineering graduates with graduates in business and social sciences, assumed to have similar unobserved skills. Finally, the sample is limited 
Table 9.5 Returns to engineering degrees and occupations in Thailand

\begin{tabular}{|c|c|c|c|c|}
\hline \multirow[t]{4}{*}{ Variables } & (1) & (2) & (3) & (4) \\
\hline & Entire & Entire & Selected & Engineering \\
\hline & Sample & Sample & Postsecondary & Degrees \\
\hline & \multicolumn{4}{|c|}{ Dependent Variable: Log Real Monthly Wages } \\
\hline \multirow{3}{*}{ Education } & & & & \\
\hline & $-0.269 * * *$ & & & \\
\hline & $(0.013)$ & & & \\
\hline \multirow[t]{2}{*}{ Humanities and Fine Arts } & $-0.267 * * *$ & & & \\
\hline & $(0.016)$ & & & \\
\hline \multirow{3}{*}{$\begin{array}{l}\text { Social Sciences, Business, and } \\
\text { Law }\end{array}$} & $-0.276^{* * *}$ & & & \\
\hline & & & & \\
\hline & $(0.012)$ & & & \\
\hline \multirow[t]{2}{*}{ Science } & $-0.209 * * *$ & & & \\
\hline & $(0.015)$ & & & \\
\hline \multirow[t]{2}{*}{ Agriculture } & $-0.238 * * *$ & & & \\
\hline & $(0.019)$ & & & \\
\hline \multirow[t]{2}{*}{ Health and Social Services } & $-0.031 * *$ & & & \\
\hline & $(0.014)$ & & & \\
\hline \multirow[t]{2}{*}{ Services } & $-0.298 * * *$ & & & \\
\hline & $(0.022)$ & & & \\
\hline \multirow[t]{2}{*}{ Manufacturing } & $-0.167 * * *$ & & & \\
\hline & $(0.030)$ & & & \\
\hline \multirow[t]{2}{*}{ Architecture } & $-0.102 * * *$ & & & \\
\hline & $(0.023)$ & & & \\
\hline \multirow[t]{2}{*}{ Engineering Degree } & & $0.059 * * *$ & $0.065 * * *$ & \\
\hline & & $(0.017)$ & $(0.019)$ & \\
\hline \multirow[t]{2}{*}{ Engineering Job } & & $0.118^{* * *}$ & $0.098 * * *$ & $0.305 * * *$ \\
\hline & & $(0.014)$ & $(0.029)$ & $(0.027)$ \\
\hline \multirow[t]{2}{*}{ Female Indicator } & & $-0.038 * * *$ & $-0.076^{* * *}$ & 0.064 \\
\hline & & $(0.005)$ & $(0.009)$ & $(0.064)$ \\
\hline \multirow{2}{*}{$\begin{array}{l}\text { Engineering Degree Matched } \\
\text { with Engineering Job }\end{array}$} & & $0.243 * * *$ & $0.246^{* * *}$ & \\
\hline & & $(0.028)$ & $(0.039)$ & \\
\hline \multirow[t]{2}{*}{ Female $\mathrm{X}$ Engineering Degree } & & $0.097 *$ & $0.125^{* *}$ & \\
\hline & & $(0.058)$ & $(0.063)$ & \\
\hline \multirow{2}{*}{$\begin{array}{l}\text { Female X Engineering } \\
\text { Occupation }\end{array}$} & & $-0.051^{*}$ & -0.075 & -0.003 \\
\hline & & $(0.026)$ & $(0.049)$ & $(0.102)$ \\
\hline \multirow{2}{*}{$\begin{array}{l}\text { Female X Eng. Degree X Eng. } \\
\text { Occupation }\end{array}$} & & 0.022 & 0.022 & \\
\hline & & $(0.095)$ & $(0.111)$ & \\
\hline \multirow[t]{2}{*}{ MA/PhD Degree Indicator } & $0.324 * * *$ & $0.314^{* * *}$ & $0.434 * * *$ & $0.270 * * *$ \\
\hline & $(0.007)$ & $(0.007)$ & $(0.012)$ & $(0.043)$ \\
\hline \multirow[t]{2}{*}{ Age } & $0.039 * * *$ & $0.041 * * *$ & $0.039 * * *$ & $0.094 * * *$ \\
\hline & $(0.002)$ & $(0.002)$ & $(0.004)$ & $(0.013)$ \\
\hline
\end{tabular}


Table 9.5 (continued)

\begin{tabular}{|c|c|c|c|c|}
\hline \multirow[t]{5}{*}{ Variables } & (1) & $(2)$ & (3) & (4) \\
\hline & Entire & Entire & Selected & Engineering \\
\hline & Sample & Sample & Postsecondary & Degrees \\
\hline & & & Degrees & Only \\
\hline & \multicolumn{4}{|c|}{ Dependent Variable: Log Real Monthly Wages } \\
\hline \multirow[t]{2}{*}{$\mathrm{Age}^{2}$} & 0.000 & -0.000 & 0.000 & $-0.001 * * *$ \\
\hline & $(0.000)$ & $(0.000)$ & $(0.000)$ & $(0.000)$ \\
\hline \multirow[t]{2}{*}{ Urban Indicator } & $0.033^{* * *}$ & $0.043 * * *$ & $0.045 * * *$ & -0.003 \\
\hline & $(0.007)$ & $(0.008)$ & $(0.013)$ & $(0.042)$ \\
\hline \multirow[t]{2}{*}{ Married Indicator } & $0.060 * * *$ & $0.054 * * *$ & $0.064 * * *$ & 0.033 \\
\hline & $(0.005)$ & $(0.005)$ & $(0.009)$ & $(0.033)$ \\
\hline \multirow[t]{2}{*}{ Public Employee Indicator } & 0.007 & $0.044 * * *$ & $-0.062 * * *$ & $-0.208 * * *$ \\
\hline & $(0.006)$ & $(0.006)$ & $(0.009)$ & $(0.030)$ \\
\hline \multirow[t]{2}{*}{ Central Region } & $-0.294 * * *$ & $-0.294^{* * *}$ & $-0.251 * * *$ & $-0.280 * * *$ \\
\hline & $(0.008)$ & $(0.008)$ & $(0.012)$ & $(0.034)$ \\
\hline \multirow[t]{2}{*}{ Northern Region } & $-0.406^{* * *}$ & $-0.400 * * *$ & $-0.408 * * *$ & $-0.442 * * *$ \\
\hline & $(0.009)$ & $(0.009)$ & $(0.014)$ & $(0.048)$ \\
\hline \multirow[t]{2}{*}{ Northeastern Region } & $-0.390 * * *$ & $-0.390 * * *$ & $-0.395 * * *$ & $-0.505 * * *$ \\
\hline & $(0.009)$ & $(0.009)$ & $(0.014)$ & $(0.047)$ \\
\hline \multirow[t]{2}{*}{ Southern Region } & $-0.408 * * *$ & $-0.403^{* * *}$ & $-0.404 * * *$ & $-0.405 * * *$ \\
\hline & $(0.009)$ & $(0.009)$ & $(0.015)$ & $(0.054)$ \\
\hline \multirow[t]{2}{*}{ Year 2008} & 0.003 & 0.011 & -0.004 & $-0.090^{*}$ \\
\hline & $(0.008)$ & $(0.008)$ & $(0.015)$ & $(0.046)$ \\
\hline \multirow[t]{2}{*}{ Year 2009} & $-0.028 * * *$ & $-0.028 * * *$ & $-0.054 * * *$ & $-0.071 * *$ \\
\hline & $(0.006)$ & $(0.006)$ & $(0.010)$ & $(0.031)$ \\
\hline \multirow[t]{2}{*}{ Constant } & $8.485 * * *$ & $8.223 * * *$ & $8.283^{* * *}$ & $7.444 * * *$ \\
\hline & $(0.042)$ & $(0.041)$ & (0.073) & $(0.241)$ \\
\hline Observations & 35,066 & 35,066 & 13,705 & 1,407 \\
\hline R-squared & 0.539 & 0.532 & 0.507 & 0.531 \\
\hline
\end{tabular}

Notes:

Standard errors in parentheses.

$* * * \mathrm{p}<0.01, * * \mathrm{p}<0.05, * \mathrm{p}<0.1$.

$\mathrm{MA}=$ master's degree, $\mathrm{PHD}=$ doctorate.

Source: Authors' calculations.

to engineers, looking at the returns to advanced degrees and job market matching.

The first specification indicates that those who hold postsecondary engineering degrees do relatively well in the labor market compared with those holding other postsecondary degrees. In fact, on average, engineering 
degree holders earn more than any other type of degree holder, with the exception of those in health and services, which includes doctors. Specification 2 shows that on average there is a $6 \%$ wage premium for engineering graduates compared with others. Furthermore, wages for engineers are $12 \%$ above those in other occupations. Engineer graduates working as engineers can expect an additional $24 \%$ wage premium. Thus, the overall premium for men with engineering degrees employed in engineering is $42 \%$ compared with male graduates in other fields working as non-engineers. After taking into account interactions between female, engineering degree, and engineering occupation variables, women can expect to earn $45 \%$ more than men with degrees and jobs outside engineering - indicating that women on average earn relatively high salaries in Thailand when matching their engineering degree with an engineering occupation.

Following Webber (2014b), the returns to engineering degrees are compared with business and social science degrees to minimize the ability bias. The results are similar to specification 2. Both male and female engineering graduates matched with engineering jobs can expect an average $42 \%$ higher wage than business and social science graduates. It is clear that, relative to those who finish other postsecondary degrees, engineering graduates on average earn significantly more in Thailand (Figures 9.1 and 9.2).

The final specification focuses only on engineering graduates and the impact of job-matching on wages. Engineering graduates with engineering jobs earn 31\% more than engineering graduates working elsewhere. In addition, those with advanced engineering degrees $(\mathrm{MA} / \mathrm{PhD})$ can expect to earn on average an additional $27 \%$ over those with only a bachelor's degree. Female and male engineers also appear to have similar wage

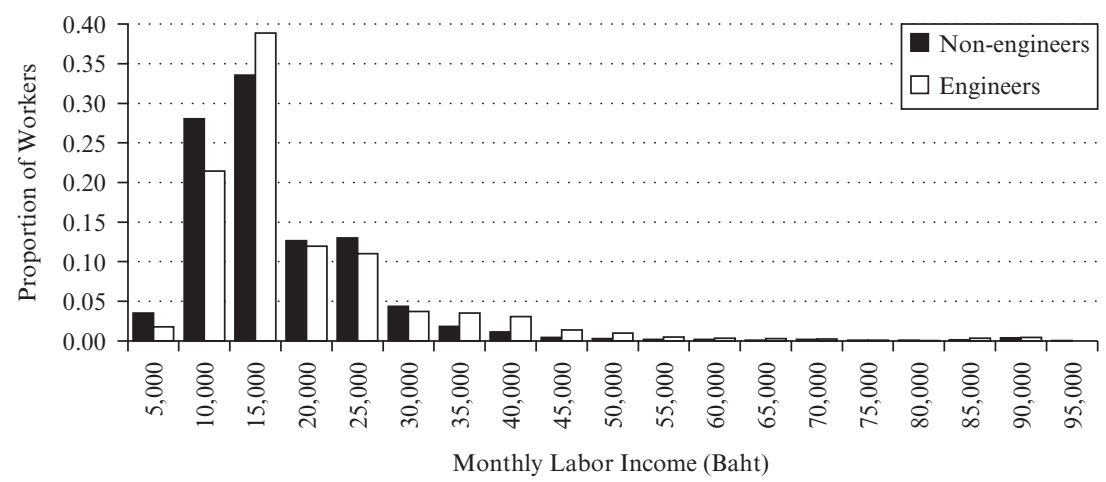

Source: Authors' calculations.

Figure 9.1 Distribution of real monthly wages by engineering occupation 


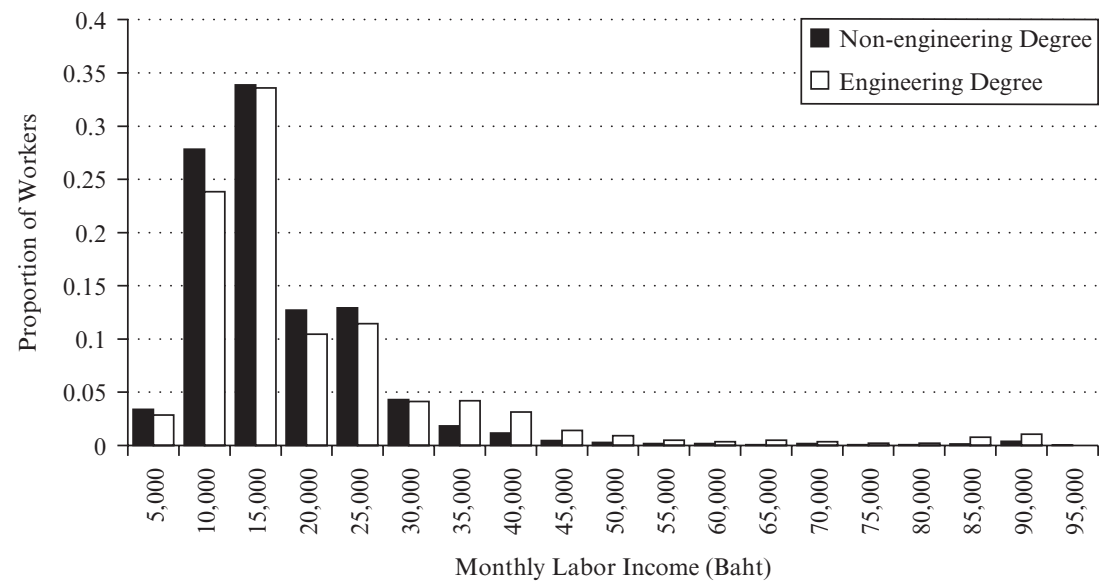

Source: Authors' calculations.

Figure 9.2 Distribution of real monthly wages by engineering degree

returns matching engineering occupations. In sum, the rate of return to engineering degrees/jobs is relatively high, especially for those matching engineering degrees with engineering work.

\section{DISCUSSION}

As of December 2016, 158 Thai engineers were Registered Foreign Professional Engineers (RFPEs) under the ASEAN MRA. Why so few? The framework of migration costs and benefits for skilled workers might hold an answer. Migration costs can be direct or indirect. Direct costs include travel and any other monetary outlays needed to migrate (job search and visa processing, among others). Non-monetary costs can include the psychological cost of leaving social networks (including family) and difficulties in a new environment. Furthermore, based on the survey of ASEAN employers on skills and competitiveness by the ILO (2014, p. 27), language plays a major role.

The ASEAN MRA essentially reduces migration costs in two ways. First, it reduces potential monetary costs of gaining country-specific professional certifications. And, second, it should in theory overcome non-monetary costs associated with obtaining permission to work abroad, especially where there is limited scope for foreign professionals to work in engineering. The question is whether these reductions in direct and 
indirect costs of migration offset costs enough so the benefits of migration outweigh its costs.

In Thailand, one potentially important non-monetary cost is the psychological cost of leaving family. According to Knodel et al. (2015, p. 10), it is quite common for adult children to stay with their parents in extended family units - instrumental in old-age support. Although co-residence fell from $77 \%$ in 1986 to $55 \%$ in 2014, the number remains significant. This could create a significant non-monetary barrier to migration among those with tight family obligations. Also, from the family perspective, skilled-labor mobility is a sensitive topic compared with low-skill workers. Access to foreign labor markets for other family members, particularly spouses, could be a major barrier in deciding to work abroad (Kahanec 2012).

There are two monetary considerations. First is an engineer's higher wages vis-à-vis the rest of Thailand's labor market. Second is the differential in pay between what engineers can earn at home and what they can expect abroad. On the first, the empirical investigation of LFS data strongly suggests engineering graduates can expect to find formal employment, have a good chance of matching their education and occupation compared with other fields, and have higher relative wage returns than those with other postsecondary degrees. As to the second, the average wages for Thailand's engineers are above other ASEAN countries, with the exception of Malaysia and Singapore (Figure 9.3).

Interestingly, even though average wages in Singapore are well above those in other ASEAN countries, the MRA may not attract engineers from Thailand, as Singapore already had mechanisms in place that allow engineers from nearby countries to legally enter and work in the country. In fact, according to Fukunaga (2015), prior to the MRA engineers could already apply to legally work in Brunei Darussalam, Cambodia, Malaysia, Singapore, the Philippines, and Thailand.

And according to the ASEAN engineering MRA, engineers working in other ASEAN countries have to practice under the supervision of a qualified engineer in the host country. This makes procuring a position more difficult and discourages work overseas. Also, there are no supporting government policies - such as tax or financial incentives-to encourage Thailand's engineers to work abroad, as opposed to engineers in Singapore and Malaysia. United Nations (2014, p.188) states that "due to the structure of the Thai economy, it is unlikely that Thailand would take substantial steps to encourage the out-migration of skilled professionals to other [ASEAN Member States], given the strong demand for such skills in Thailand and potential risk of brain drain."

There does not appear to be any impetus for Thailand's engineers to use 


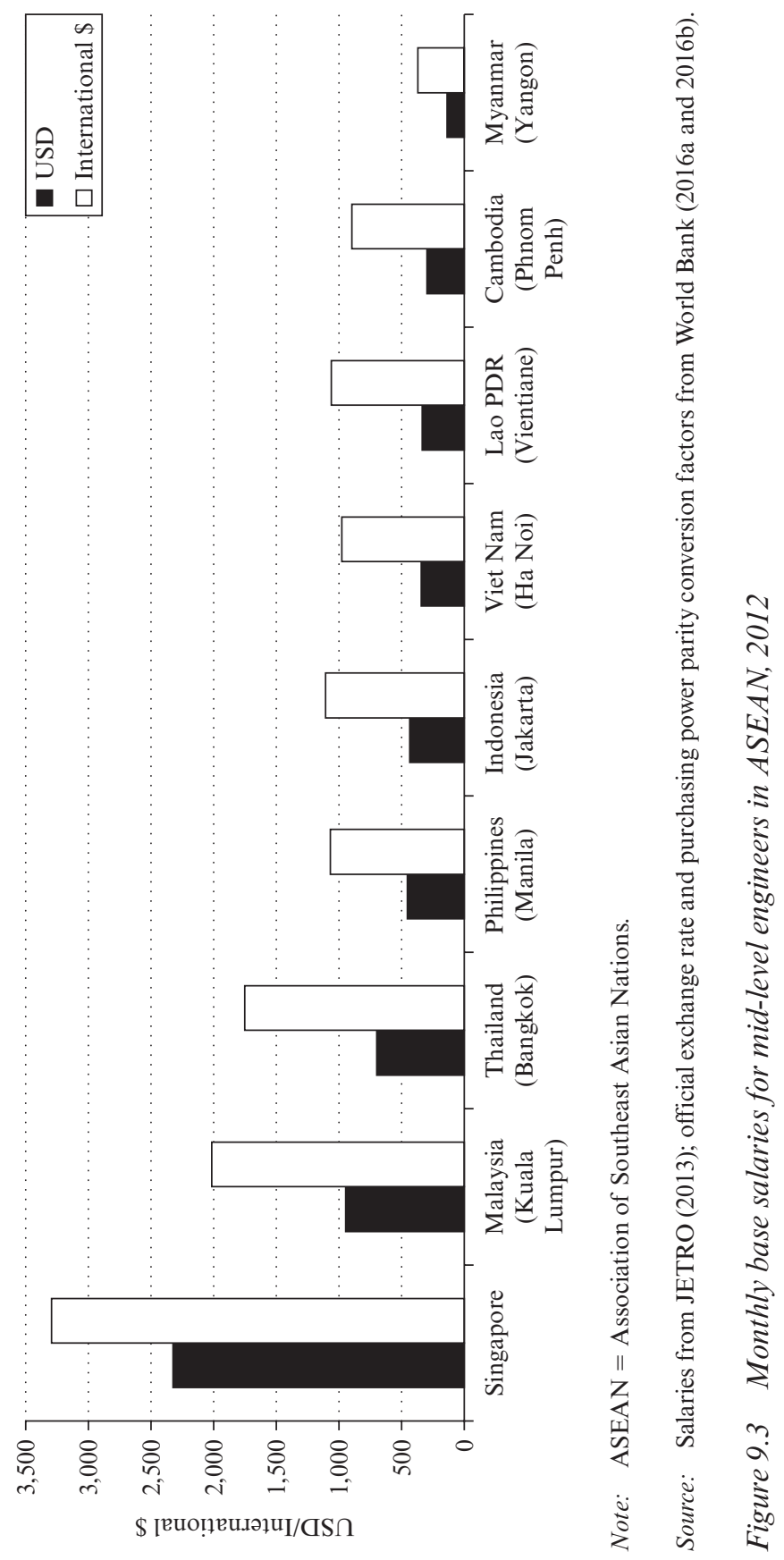


the MRA to work as engineers in other ASEAN countries. However, it is possible that engineers from other ASEAN countries may want to move and work in Thailand's engineering market, possibly increasing competition in Thailand's engineering labor market.

A recent survey by Adecco (2015) found engineering most in demand in Thailand in 2014 -indicating a supply shortage of engineers in Thailand. Manpower (2014) found that increased foreign direct investment (FDI) in manufacturing as a result of the AEC led to an increase in demand for engineers in Thailand, especially in the automobile industry. Thus, demand for engineers has been growing as the automobile sector expands-which should continue as the government moves to make the country an automobile manufacturing hub.

The relatively high returns to engineering degrees/occupations in Thailand and the relatively high salaries compared with other ASEAN countries - combined with the reduced costs of migration due to the MRA - could be attractive to engineers in the region. And Thailand's labor market is relatively woman-friendly, as demonstrated by the empirical results - another potential factor that could attract ASEAN engineers to Thailand.

Thailand is already recognized as a major recipient country for ASEAN migration (Wickramasekera 2002). Its relatively open economy has already attracted a large number of skilled and professional workers globally, with an estimated 100,000 high-skilled foreign workers with work permits in 2010 (Huguet et al. 2012, p.2). According to official statistics from the Department of Employment, Office of Foreign Workers Administration, and the Immigration Bureau, in 2012 the estimated number of foreign professional, skilled, and semi-skilled workers was 89,829 , of which 83,419 were foreigners with work permits and 6,410 diplomats and officials. Given this openness and attractiveness, the Thai Ministry of Labor (2015) expects that ASEAN MRA implementation will challenge Thai workers through greater competition from skilled workers from other ASEAN countries. The Ministry of Labor (2015) emphasizes that Thailand's workers need to adjust to the new labor realities and improve their skills, especially their English-language proficiency and proficiency in information technology (IT). However, the government has not issued any significant new regulations or policies related to the eight MRAs (United Nations 2014). The extensive use of Thai in the workplace is a difficult barrier for ASEAN engineers, as was found in the EU (Eurofound 2014). Thus, the effectiveness of ASEAN MRAs in attracting greater labor inflows remains to be seen. 


\section{CONCLUSIONS}

This chapter explored the labor market for engineers in Thailand. Three main aspects were analyzed. First, an evaluation of the demand-supply situation found that Thailand's engineering graduates match relatively well with engineering occupations. Also, the demand for engineers is high, making jobs readily available for new entrants. Second, while two-thirds of Thailand's workforce is in the informal economy, the results show that $23 \%$ of engineering degree holders and only $2 \%$ of those in engineering occupations are informally employed. Third, the rate of return to engineering degrees/jobs is relatively high compared with other degree/job fields in Thailand's skilled worker market. This is especially true for engineering graduates matched with engineering jobs, earning on average $42 \%$ more than non-engineering graduates in non-engineering jobs. In general, the analysis shows that engineers have as good as or better career prospects within Thailand in terms of formal employment and wages compared with other highly educated workers. The empirical exercise also shows that women engineers can expect similar opportunities and returns in the formal sector as their male engineering counterparts.

In terms of the costs and benefits of international labor migration, it is clear from JETRO (2013) that the monthly salaries for mid-level engineers in Thailand are higher than most other ASEAN countries (see Figure 9.3). From a non-monetary standpoint, the psychological costs of leaving family in Thailand are high, especially given extended family units and the cultural expectation to provide support to the elderly. Thus, it is unlikely many Thai engineers would use the MRA to seek employment in another ASEAN country. These results are consistent with the findings in a recent study by Fukunaga $(2015$, p.17), which indicate that one of the main challenges for MRA implementation is the lack of incentives to work overseas; and that the supply and demand in each member's labor market remains the main factor driving MRA implementation.

Given Thailand's attractive work environment - relatively high wages for the region and high demand for engineers - and modest savings in time and money due to the MRA, it is possible engineers from other ASEAN countries will consider engineering jobs in Thailand. This could mean Thai workers should upgrade their skills to survive in a more competitive environment. Thus, the Thai government and higher education institutions should consider how to prepare local engineers for a more competitive market.

Finally, if the government wants Thailand's engineers to use the MRA, it should consider providing information related to the laws and regulations in each ASEAN country as well as the benefits engineers can expect 
working overseas. According to the Center for International Trade Studies, University of the Thai Chamber of Commerce (2012), only 10\% of Thailand's engineers were aware of the benefits of free labor mobility. The government could develop a strategy to prepare for greater high-skilled labor mobility and create opportunities for engineers to work overseas. But the MRA lowers migration costs only slightly. And the high local demand for engineers, the attractive wages relative to other skilled workers, and the socio-cultural conditions that place great importance on family linkages will likely outweigh any MRA benefits.

While this chapter analyzes the state of Thailand's labor market for engineers and likely MRA impact, it has its limitations. First, it is an ex ante evaluation - as the full effect of the MRAs have yet to be felt. Follow-up studies could evaluate the ex post impact of the MRA on Thailand's engineering market. Also, due to data constraints, it was not possible to directly study the engineering labor markets in other ASEAN countries. As the AEC moves forward with legal arrangements to improve the free flow of labor, more comprehensive studies in each member country are needed to better understand the costs and benefits of these arrangements across ASEAN.

\section{NOTES}

1. http://www.onetonline.org/.

2. Employees and employers include private firm employees, government employees, government enterprise employees, and employers. Non-employees include own-account workers, unpaid family workers, and members of cooperatives. The majority of nonemployees are own-account workers.

\section{REFERENCES}

Adecco (2015), Thailand Salary Guide 2015. Bangkok: Adecco.

Arcidiacono, P., J. Hotz, A. Maurel, and T. Romano (2014), Recovering Ex Ante Returns and Preferences for Occupations Using Subjective Expectations Data. NBER Working Paper No. 20626.

Bauer, T., J. Haisken-DeNew, and C. Schmidt (2005), International Labour Migration, Economic Growth and Labour Markets: The Current State of Affairs. In: M. Macura, A. L. MacDonald, and W. Haug, eds. The New Demographic Regime: Population Challenges and Policy Responses. New York and Geneva: United Nations.

Berger, M.C. (1988), Predicted Future Earnings and Choice of College Major. Industrial and Labor Relations Review. 41(3). pp.418-29.

Black, D.A., S. Sanders, and L. Taylor (2003), The Economic Reward for Studying Economics. Economic Inquiry. 41(3). pp. 365-77. 
Blundell, R., L. Dearden, A. Goodman, and H. Reed (2000), The Returns to Higher Education in Britain: Evidence from a British Cohort. Economic Journal. 110. pp. F82-F99.

Bodker, S., R. Jacobsen, and J. Skaksen (2013), Fiscal Costs and Benefits of High Skilled Immigration to a Generous Welfare State. NORFACE Migration Discussion Paper No. 2013-06.

Bonin, H., W. Eichhorst, C. Florman, M.O. Hansen, L. Skiöld, J. Stuhler, K. Tatsiramos, H. Thomasen, and K.F. Zimmermann (2008), Geographic Mobility in the European Union: Optimising Its Economic and Social Benefits. IZA Research Report No. 19.

Borghans, L. and A. De Grip, eds (2000), An Overeducated Worker? The Economics of Skill Utilization. Cheltenham, UK and Northampton, MA, USA: Edward Elgar Publishing.

Borjas, G.J. (1987), Self-selection and the Earnings of Immigrants. American Economic Review. 77. pp. 531-53.

Bourne, C. and A. Dass (2003), Private and Social Rates of Return to Higher Education in Science and Technology in a Caribbean Economy. Education Economics. 11 (1). pp. 1-10.

Card, D. (1999), The Causal Effect of Education on Earnings. In O. Ashenfelter and D. Card, eds. Handbook of Labor Economics Vol. 3 A. Amsterdam: Elsevier Science.

Chevalier, A. (2012), To Be or Not to Be . . a Scientist. IZA Discussion Paper No. 6353. Bonn: IZA.

Eurofound (2014), Labour Migration in the EU: Recent Trends and Policies. Luxembourg: Publications Office of the EuropeanUnion, (http://digitalcommons. ilr.cornell.edu/intl/414).

European Commission (2010), Geographical and Labour Market Mobility. Special Eurobarometer. 337/ Wave 72.5, Brussels.

Fan, J. and C. Zhang (2015), A Study of the Rate of Return to Higher Engineering Education in China. International Journal of Educational Development. 42. pp. 106-14.

Fukunaga, Y. (2015), Assessing the Progress of ASEAN MRAs on Professional Services. ERIA Discussion Paper Series. ERIA-DP-2015-21.

Hoekstra, M. (2009), The Effect of Attending the Flagship State University on Earnings: A Discontinuity Based Approach. Review of Economics and Statistics. 91(4). pp. 717-24.

Huguet, J., A. Chamratrithirong, and C. Natali (2012), Thailand at a Crossroads: Challenges and Opportunities in Leveraging Migration for Development. Issue in Brief: A Joint Series of the IOM Regional Office for Asia and the Pacific and the Migration Policy Institute.

International Labour Organization (2014), Survey of ASEAN Employers on Skills and Competitiveness. Bangkok: ILO.

JETRO (2013), The 23rd Survey of Investment Related Costs in Asia and Oceania (FY 2012 survey). JETRO Report. https://www.jetro.go.jp/en/reports/survey/pdf 12013_05_01_biz.pdf.

Johnson, J. (2015), Will the ASEAN Economic Community Mean Free Movement of Labour? http://www.cipd.asia/people-management-magazine/hr-news-opinion/ asean-free-movement-labour.

Kahanec, M. (2012), Skilled Labor Flows: Lessons from the European Union, IZA Research Report No. 49. 
Kinsler, J. and R. Pavan (2015), Specificity of General Human Capital: Evidence from College Major Choice. Journal of Labor Economics. 33(4). pp. 933-72.

Knodel, J., B. Teerawichitchainan, V. Prachuabmoh, and W. Pothisiri (2015), The Situation of Thailand's Older Population: An Update based on the 2014 Survey of Older Persons in Thailand. Chiangmai: HelpAge International.

Leslie, D. (2003), Using Success to Measure Quality of British Higher Education: Which Subjects Attract the Best-qualified Students? Journal of the Royal Statistical Society. 166. pp.329-47.

Manpower (2008), Relocation for Work Survey: Global Results 2008. https://candid ate.manpower.com/wps/wcm/connect/1c0b85804ec2f47cb3d4f3ee16aecd97/WP_0 60309_RelocatingForWorkSurvey.pdf?MOD=AJPERES.

Manpower (2014), Talent Shortage Survey. Milwaukee: Manpower Group.

Migration Policy Institute (2013), Bilateral Remittance Flow. http://www.migration policy.org/programs/data-hub/global-remittances-guide.

Ministry of Labour (2015), Preparation for Flow of Labor in the ASEAN Community (Final Report) (in Thai). Bangkok. http://www.mol.go.th/sites/default/files/down loads/pdf/5._bththii_1_bthnam.pdf.

O'Leary, N.C. and P.J. Sloane (2005), The Return to a University Education in Great Britain. National Institute Economic Review. 193(1). pp. 75-89.

Orbeta, A. (2013), Enhancing Labor Mobility in ASEAN: Focus on Lower-skilled Workers. Philippine Institute for Development Studies (PIDS) Discussion Paper 2013-17.

Paweenawat, S.W. and J. Vechbanyongratana (2015), Private Returns to STEM Education in Thailand. University of the Thai Chamber of Commerce (UTCC) Working Paper.

Schmitt, V., T. Sakunphanit, and O. Prasitsiriphol (2013), Social Protection Assessment Based National Dialogue: Towards a Nationally Defined Social Protection Floor in Thailand. Bangkok: International Labour Organization.

Sjaastad, L.A. (1962), The Costs and Returns of Human Migration. Journal of Political Economy. 70. pp. S80-S93.

Sugiyarto, S. and D. Agunias (2014), A "Freer" Flow of Skilled Labour within ASEAN: Aspirations, Opportunities and Challenges in 2015 and Beyond. Bangkok and Washington, DC: International Organization for Migration and Migration Policy Institute.

Thomas, S.L. (2000), Deferred Costs and Economic Returns to College Major, Quality, and Performance. Research in Higher Education. 41(3). pp. 281-313.

University of the Thai Chamber of Commerce (2012), An Analysis of Competitive Potential of Skilled Labor in the Service Sector Free Opening under the ASEAN Economic Community (AEC). Thailand Economic and Business Review. 4(3). pp. 4-8.

United Nations (2014), Thailand Migration Report 2014. Bangkok: United Nations.

Walker, I. and Y. Zhu (2010), Differences by Degree: Evidence of the Net Financial Rates of Return to Undergraduate Study for England and Wales. Economics of Education Review. 30(6). pp. 1177-86.

Webber, D. (2014a), Are All Degrees Created (Financially) Equal: What is the Return to Education, and Is It the Same for Everybody? IZA World of Labor. 92. pp. $1-10$.

Webber, D. (2014b), The Lifetime Earnings Premia of Different Majors: Correcting for Selection Based on Cognitive, Noncognitive, and Unobserved Factors. Labour Economics. 28. pp. 14-23. 
Wickramasekera, P. (2002), Asian Labor Migration: Issues and Challenges in an Era of Globalization. Geneva: International Labour Office.

World Bank (2016a), Global Economic Monitor (GEM). Retrieved from http://data bank.worldbank.org/data/reports.aspx?source=global-economic-monitor-(gem). World Bank (2016b), PPP Conversion Factor, GDP (LCU per International \$). Retrieved from http://data.worldbank.org/indicator/PA.NUS.PPP. 